\title{
Predictors of mortality for patients with COVID-19 pneumonia caused by SARS- CoV-2: a prospective cohort study
}

\author{
Rong-Hui Du ${ }^{1,3}$, Li-Rong Liang ${ }^{2,3}$, Cheng-Qing Yang ${ }^{1,3}$, Wen Wang ${ }^{2,3}$, \\ Tan-Ze Cao ${ }^{1}$, Ming Li ${ }^{1}$, Guang-Yun Guo ${ }^{1}$, Juan Du ${ }^{1}$, Chun-Lan Zheng ${ }^{1}$, Qi Zhu ${ }^{1}$, \\ Ming $\mathrm{Hu}^{1}$, Xu-Yan $\mathrm{Li}^{2}$, Peng Peng ${ }^{1,4}$ and Huan-Zhong Shi $\mathbb{C}^{2,4}$
}

Affiliations: ${ }^{1}$ Dept of Respiratory and Critical Care Medicine, Wuhan Pulmonary Hospital, Wuhan, China. ${ }^{2}$ Dept of Respiratory and Critical Care Medicine, Beijing Chao-Yang Hospital, Capital Medical University, Beijing, China. ${ }^{3}$ These authors contributed equally. ${ }^{4}$ These authors are joint principal authors.

Correspondence: Huan-Zhong Shi, Dept of Respiratory and Critical Care Medicine, Beijing Chao-Yang Hospital, Capital Medical University, 8 Gongti Nanlu, Chao-Yang District, Beijing 100020, China.

E-mail: shihuanzhongdsina.com

@ERSpublications

These data showed that age $\geqslant 65$ years, pre-existing concurrent cardiovascular or cerebrovascular diseases, $\mathrm{CD}^{+} \mathrm{CD8}^{+} \mathrm{T}$-cells $\leqslant 75$ cells $\cdot \mu \mathrm{L}^{-1}$ and cardiac troponin $\mathrm{I} \geqslant 0.05 \mathrm{ng} \cdot \mathrm{mL}^{-1}$ were four risk factors predicting high mortality of COVID-19 pneumonia patients https://bit.ly/2Rh6Nqv

Cite this article as: Du R-H, Liang L-R, Yang C-Q, et al. Predictors of mortality for patients with COVID19 pneumonia caused by SARS-CoV-2: a prospective cohort study. Eur Respir J 2020; 55: 2000524 [https:// doi.org/10.1183/13993003.00524-2020].

ABSTRACT The aim of this study was to identify factors associated with the death of patients with COVID-19 pneumonia caused by the novel coronavirus SARS-CoV-2.

All clinical and laboratory parameters were collected prospectively from a cohort of patients with COVID-19 pneumonia who were hospitalised to Wuhan Pulmonary Hospital (Wuhan City, Hubei Province, China) between 25 December 2019 and 7 February 2020. Univariate and multivariate logistic regression was performed to investigate the relationship between each variable and the risk of death of COVID-19 pneumonia patients.

In total, 179 patients with COVID-19 pneumonia (97 male and 82 female) were included in the present prospective study, of whom 21 died. Univariate and multivariate logistic regression analysis revealed that age $\geqslant 65$ years (OR 3.765, 95\% CI 1.201-11.803; $\mathrm{p}=0.023$ ), pre-existing concurrent cardiovascular or cerebrovascular diseases (OR 2.464, 95\% CI 1.279-4.747; $\mathrm{p}=0.007), \mathrm{CD}^{+} \mathrm{CD}^{+} \mathrm{T}$-cells $\leqslant 75$ cells. $\mu \mathrm{L}^{-1}(\mathrm{OR}$ 3.982, 95\% CI 1.761-9.004; $\mathrm{p}<0.001$ ) and cardiac troponin $\mathrm{I} \geqslant 0.05 \mathrm{ng} \cdot \mathrm{mL}^{-1}$ (OR 4.077, 95\% CI $1.778^{-}$ 9.349; $\mathrm{p}<0.001)$ were associated with an increase in risk of mortality from COVID-19 pneumonia. In a sex-, age- and comorbid illness-matched case-control study, $\mathrm{CD}^{+} \mathrm{CD} 8^{+} \mathrm{T}$-cells $\leqslant 75$ cells $\mu \mathrm{L}^{-1}$ and cardiac troponin $\mathrm{I} \geqslant 0.05 \mathrm{ng} \cdot \mathrm{mL}^{-1}$ remained as predictors for high mortality from COVID-19 pneumonia.

We identified four risk factors: age $\geqslant 65$ years, pre-existing concurrent cardiovascular or cerebrovascular diseases, $\mathrm{CD}^{+} \mathrm{CD}^{+} \mathrm{T}$-cells $\leqslant 75$ cells $\mu \mathrm{L}^{-1}$ and cardiac troponin $\mathrm{I} \geqslant 0.05 \mathrm{ng} \cdot \mathrm{mL}^{-1}$. The latter two factors, especially, were predictors for mortality of COVID-19 pneumonia patients.

This article has been revised according to the author correction published in the September 2020 issue of the European Respiratory Journal.

This article has supplementary material available from erj.ersjournals.com

Received: 02 March 2020 | Accepted after revision: 30 March 2020

Copyright $\odot$ ERS 2020. This article is open access and distributed under the terms of the Creative Commons Attribution Non-Commercial Licence 4.0. 


\section{Introduction}

In December 2019, a new contagious disease, named COVID-19 pneumonia and caused by a novel coronavirus (SARS-CoV-2), emerged in Wuhan City, Hubei Province, China, and is now spreading across international borders [1-3]. By 12 February 2020, 189 medical teams consisting of 21569 doctors and nurses from 29 provinces of China had been sent to Hubei Province to deal with COVID-19 pneumonia [4]. The ongoing COVID-19 pneumonia pandemic is currently not under control, with a high risk of spread in China and globally. As of 22 March 2020, a total of 307297 confirmed cases had been reported in at least 169 countries [5]. Unfortunately, the effect of the outbreak of COVID-19 pneumonia and the ultimate scope are unclear, as the situation is rapidly evolving $[6,7]$. As a matter of fact, the fear of the ongoing COVID-19 epidemic was and is playing a major role in the economic and social consequences.

In the first published cohort of 41 patients with COVID-19 pneumonia from Wuhan Jinyintan Hospital, six $(14.6 \%)$ patients worsened in a short period of time and died of multiple organ failure [8]; when the cohort size expanded to 99 cases, 11 (11.1\%) patients died [9]. In another Wuhan cohort of hospitalised patients with COVID-19 pneumonia, the overall mortality was $4.3 \%$ (six out of 138) [10]. The findings from these three previous studies suggested that older age and underlying comorbidities were associated with disease severity or death of COVID-19 pneumonia patients [8-10]. Between 25 December 2019 and 7 February 2020, a total of 179 adult patients with COVID-19 pneumonia were hospitalised to Wuhan Pulmonary Hospital, a special hospital for isolating and treating patients with infectious diseases. As of 24 March 2020, 158 patients had been discharged and the remaining 21 had died. In the present study, we sought to identify the clinical and laboratory parameters associated with mortality of patients with COVID-19 pneumonia.

\section{Methods}

\section{Patients}

This study was conducted in accordance with the approved guidelines of the Institutional Review Board of Wuhan Pulmonary Hospital (wufeilunli-2020-02). The need for written informed consent from each patient was waived since we prospectively collected and analysed all data from each patient according to the policy for public health outbreak investigation of emerging infectious diseases issued by the National Health Commission of the People's Republic of China.

Between 25 December 2019 and 7 February 2020, a single-centre case cohort of 179 consecutive patients with confirmed and probable COVID-19 pneumonia was hospitalised to Wuhan Pulmonary Hospital; these patients were all included in the present study. The probable and definite diagnosis of COVID-19 pneumonia was established according to the case definition established by World Health Organization interim guidance [11].

\section{Data collection and analysis}

The information for all patients, including demographic data, clinical characteristics, laboratory parameters and outcomes, were collected prospectively upon hospital admission. Two researchers independently reviewed the data collection forms to double-check the collected data.

Descriptive statistics included frequency analysis (percentages) for categorical variables and mean $\pm \mathrm{SD}$ or median and interquartile range for continuous variables. Comparisons were determined by t-test or Mann-Whitney U-test for continuous variables, as appropriate, and by the use of the Chi-squared test or Fisher exact test for categorical variables. Univariate and multivariate logistic regression was performed to explore the association of clinical characteristics and laboratory parameters and the risk of death. The backward conditional method was used to select imaging variables entering the scoring system. The statistical significance level was set at 0.05 (two-tailed). All analyses were conducted with MedCalc (MedCalc Software Ltd, Ostend, Belgium) and SPSS version 23.0 (IBM, Armonk, NY, USA) statistical software.

\section{Results}

\section{Clinical data}

This report describes a COVID-19 pneumonia cohort of 179 patients who were hospitalised to Wuhan Pulmonary Hospital between 25 December 2019 and 7 February 2020, of whom 136 (76\%) were diagnosed definitely as having COVID-19 pneumonia with a positive SARS-CoV-2 test result; the remaining $43(24 \%)$ were diagnosed clinically. The mean \pm SD time between onset of symptoms and hospitalisation was $9.7 \pm 4.3$ days. The mean \pm SD age was $57.6 \pm 13.7$ years (range 18-87 years), and 97 (54.2\%) were men (table 1$)$. Of 179 patients, 21 (11.7\%) worsened in a short period of time and died of multiple organ failure, especially respiratory failure and heart failure, and the mean $\pm \mathrm{SD}$ duration from admission to death was $13.7 \pm 8.3$ days (range 3-33 days) (supplementary table $S 1$ ). 


\begin{tabular}{|c|c|c|c|c|}
\hline Characteristics & Total & Deceased & Survivors & p-value \\
\hline Patients & 179 & 21 & 158 & \\
\hline Age years & $57.6 \pm 13.7$ & $70.2 \pm 7.7$ & $56.0 \pm 13.5$ & $<0.001$ \\
\hline Sex & & & & 0.642 \\
\hline Male & $97(54.2)$ & $10(47.6)$ & $87(55.1)$ & \\
\hline Female & 82 (45.8) & $11(52.4)$ & $71(44.9)$ & \\
\hline \multicolumn{5}{|l|}{ Underlying diseases } \\
\hline Hypertension & $58(32.4)$ & $13(61.9)$ & 45 (28.5) & 0.005 \\
\hline Cardiovascular or cerebrovascular diseases & $29(16.2)$ & $12(57.1)$ & $17(10.8)$ & $<0.001$ \\
\hline Diabetes & $33(18.4)$ & $6(28.6)$ & $27(17.1)$ & 0.231 \\
\hline Chronic digestive disorders & $21(11.7)$ & $4(19.0)$ & $17(10.8)$ & 0.279 \\
\hline Tuberculosis & $8(4.5)$ & $0(0)$ & $8(5.1)$ & 0.599 \\
\hline Chronic hepatic or renal insufficiency & $4(2.2)$ & $2(9.5)$ & $2(1.3)$ & 0.068 \\
\hline Peripheral vascular disease & $4(2.2)$ & $2(9.5)$ & $2(1.3)$ & 0.068 \\
\hline Malignancy & $4(2.2)$ & $1(4.8)$ & $3(1.9)$ & 0.396 \\
\hline \multicolumn{5}{|l|}{ Symptoms } \\
\hline Fever & $177(98.9)$ & $21(100)$ & $156(98.7)$ & 1.000 \\
\hline Dry cough & $146(81.6)$ & $14(66.7)$ & $132(83.5)$ & 0.074 \\
\hline Dyspnoea & $89(49.7)$ & $18(85.7)$ & $71(44.9)$ & $<0.001$ \\
\hline Fatigue & $71(39.7)$ & $13(61.9)$ & $58(36.7)$ & 0.033 \\
\hline Sputum production & $55(30.7)$ & $12(57.1)$ & $43(27.2)$ & 0.010 \\
\hline Gastrointestinal symptoms & $39(21.8)$ & $8(38.1)$ & $31(19.6)$ & 0.087 \\
\hline Myalgia & $34(19.0)$ & 7 (33.3) & $27(17.1)$ & 0.083 \\
\hline Headache & $17(9.5)$ & $5(23.8)$ & $12(7.6)$ & 0.033 \\
\hline Haemoptysis & $10(5.6)$ & $0(0)$ & $10(6.3)$ & 0.609 \\
\hline Systolic blood pressure $\mathrm{mmHg}$ & & NA & $122.4 \pm 18.6$ & \\
\hline Diastolic blood pressure $\mathrm{mmHg}$ & & NA & $77.9 \pm 10.0$ & \\
\hline Temperature ${ }^{\circ} \mathrm{C}$ & & & & 0.156 \\
\hline$<37.3$ & $109(60.9)$ & $16(76.2)$ & 93 (58.9) & \\
\hline$\geqslant 37.3$ & $70(39.1)$ & $5(23.8)$ & $65(41.1)$ & \\
\hline Respiratory rate breaths. $\min ^{-1}$ & $20.0(20.0-21.0)$ & $20.0(20.0-34.5)$ & $20.0(20.0-21.0)$ & 0.016 \\
\hline Heart rate beats $\mathrm{min}^{-1}$ & $86.0(78.0-100)$ & $94.0(78.0-109.5)$ & $85.5(78.0-99.3)$ & 0.150 \\
\hline
\end{tabular}

Data are presented as $\mathrm{n}$, mean $\pm \mathrm{SD}, \mathrm{n}(\%)$ or median (interquartile range), unless otherwise stated. NA: not available.

As shown in table 1, the patients in the deceased group were much older than those in the survivor group (70.2 \pm 7.7 years versus $56.0 \pm 13.5$ years; $\mathrm{p}<0.001)$. We noted that more patients in the deceased group had hypertension $(61.9 \%$ versus $28.5 \% ; \mathrm{p}=0.005)$ and cardiovascular or cerebrovascular diseases $(57.1 \%$ versus $10.8 \% ; \mathrm{p}<0.001$ ), and that there was no difference in the incidence of diabetes, chronic digestive disorders, tuberculosis, chronic hepatic or renal insufficiency, peripheral vascular disease or malignancy between the two groups (all $\mathrm{p}>0.05$ ).

Very similarly to the findings reported in the previous studies [8-10, 12], we noted that the top five common symptoms included fever (98.9\% of the patients), dry cough (81.6\%), dyspnoea (49.7\%), fatigue (39.7\%) and sputum production (30.7\%) on admission among the total population (table 1). Except for dyspnoea, fatigue, sputum production and headache, which were more frequently present in the deceased group than in the survivor group (85.7\% versus $44.9 \%(\mathrm{p}<0.001), 61.9 \%$ versus $36.7 \%(\mathrm{p}=0.033), 57.1 \%$ versus $27.2 \%(\mathrm{p}=0.010)$ and $23.8 \%$ versus $7.6 \%(\mathrm{p}=0.033)$, respectively), other kinds of symptoms were similar in the two groups. Patients in the deceased group had a higher respiratory rate than those in the survivor group $(\mathrm{p}=0.016)$; there was no difference in heart rate.

\section{Laboratory findings}

Potentially due to the presence of secondary bacterial infection, as suggested by higher concentrations of C-reactive protein and procalcitonin, the deceased had more white blood cells and neutrophils than did the survivors (table 2). In fact, lung secondary bacterial infections were documented at a late stage of disease in 10 of the 21 deceased patients, and the aetiological spectrum included Klebsiella pneumoniae, Staphylococcus, Acinetobacter baumannii and Escherichia coli. As expected, the deceased had reduced lymphocytes compared to the survivors. One remarkable finding was that absolute numbers of $\mathrm{CD} 3{ }^{+} \mathrm{CD} 8^{+}$ T-cells, but not $\mathrm{CD}^{+} \mathrm{CD}^{+} \mathrm{T}$-cells, were significantly reduced in the deceased compared to the survivors. 
TABLE 2 Laboratory findings in patients with COVID-19 pneumonia

\begin{tabular}{|c|c|c|c|c|}
\hline Characteristics & Total & Deceased & Survivors & p-value \\
\hline Patients & 179 & 21 & 158 & \\
\hline White blood cells $\times 10^{9}$ cells. $\mathrm{L}^{-1}$ & $5.3(3.9-7.8)$ & $8.9(4.8-13.1)$ & $5.1(3.8-7.3)$ & 0.003 \\
\hline Lymphocytes $\times 10^{9}$ cells $\cdot \mathrm{L}^{-1}$ & $0.8(0.6-1.1)$ & $0.7(0.5-0.8)$ & $0.8(0.6-1.1)$ & 0.046 \\
\hline \multicolumn{5}{|l|}{ T-cell subsets } \\
\hline $\mathrm{CD}^{+} \mathrm{CD}^{+}$cells $\mu \mathrm{L}^{-1}$ & $114.3(62.9-195.3)$ & $68.0(55.1-148.8)$ & $128.3(73.5-201.7)$ & 0.066 \\
\hline Procalcitonin $\mathrm{ng} \cdot \mathrm{mL}^{-1}$ & $0.1(0.0-0.2)$ & $0.1(0.1-0.5)$ & $0.1(0.0-0.2)$ & 0.013 \\
\hline Cardiac troponin I $\mathrm{ng} \cdot \mathrm{mL}^{-1}$ & $0.0(0.0-0.1)$ & $0.1(0.0-0.8)$ & $0.0(0.0-0.0)$ & $<0.001$ \\
\hline Myoglobin $\mathrm{ng} \cdot \mathrm{mL}^{-1}$ & $36.9(18.4-124.0)$ & $162.0(48.5-342.8)$ & $32.3(15.5-60.3)$ & $<0.001$ \\
\hline Brain natriuretic peptide $\mathrm{pg} \cdot \mathrm{mL}^{-1}$ & $645.0(110.0-1504.0)$ & $970.0(620.5-3531.0)$ & $390.0(58.0-1118.5)$ & 0.004 \\
\hline Albumin $\mathrm{g} \cdot \mathrm{L}^{-1}$ & $33.2(30.7-36.4)$ & $33.2(31.2-35.6)$ & $33.0(30.6-38.1)$ & 0.764 \\
\hline Total bilirubin $\mu \mathrm{mol} \cdot \mathrm{L}^{-1}$ & $8.9(6.6-12.5)$ & $9.6(8.3-16.3)$ & $8.7(6.5-12.3)$ & 0.146 \\
\hline Creatinine $\mu \mathrm{mol} \cdot \mathrm{L}^{-1}$ & $66.5(55.8-82.0)$ & $95.0(63.0-112.0)$ & $65.0(55.0-80.0)$ & 0.001 \\
\hline D-dimer $\mathrm{mg} \cdot \mathrm{L}^{-1}$ & $0.5(0.3-1.7)$ & $1.1(0.4-10.5)$ & $0.5(0.3-1.2)$ & 0.011 \\
\hline Prothrombin time s & $13.7(12.4-15.4)$ & $13.9(12.3-16.3)$ & $13.7(12.4-15.2)$ & 0.758 \\
\hline Activated partial thromboplastin time s & $35.6(31.0-39.4)$ & $37.8(30.8-41.5)$ & $35.3(30.9-39.1)$ & 0.383 \\
\hline$P_{\mathrm{aO}_{2}} \mathrm{mmHg}$ & $72.0(57.0-88.0)$ & $56.0(49.0-71.0)$ & $74.5(59.0-92.0)$ & 0.001 \\
\hline$P_{\mathrm{aCO}_{2}} \mathrm{mmHg}$ & $37.0(33.0-41.0)$ & $34.0(29.0-41.0)$ & $37.0(34.0-41.0)$ & 0.068 \\
\hline$P_{\mathrm{aO}_{2}}: F_{\mathrm{IO}_{2}} \mathrm{mmHg}$ & $249.6 \pm 106.1$ & $185.5 \pm 64.8$ & $261.5 \pm 108.2$ & 0.002 \\
\hline
\end{tabular}

Data are presented as $\mathrm{n}$, median (interquartile range) or mean $\pm \mathrm{SD}$, unless otherwise stated. $P_{\mathrm{aO}}$ : arterial oxygen tension; $P_{\mathrm{aco}}$ : arterial carbon dioxide tension; $F_{\mathrm{IO}_{2}}$ : inspiratory oxygen fraction.

Compared to the patients in the survivor group, those in the deceased group underwent more frequent and more severe heart injury, as all laboratory parameters reflecting heart function, including cardiac troponin I, myoglobin and brain natriuretic peptide, were all significantly elevated in the deceased (tables 2 and 3). The deceased were more susceptible to hepatic or renal insufficiency, and to respiratory failure, indicated by the elevation of aspartate aminotransferase or creatinine, and the reduction of arterial oxygen tension $\left(P_{\mathrm{aO}_{2}}\right)$ and the ratio of $P_{\mathrm{aO}_{2}}$ to inspiratory oxygen fraction $\left(\mathrm{F}_{\mathrm{IO}_{2}}\right)$.

\section{Predictors of mortality}

For all demographic data, clinical presentation data and laboratory findings presented in tables 1 and 2, we initially evaluated, using univariate analysis, each variable that displayed a statistically significant difference $(\mathrm{p}<0.05)$ between nonsurvivors and survivors. Our analysis revealed that age $\geqslant 65$ years, hypertension, cardiovascular or cerebrovascular diseases, dyspnoea, fatigue, sputum production, headache, white blood cell count $>10 \times 10^{9}$ cells $\mathrm{L}^{-1}$, neutrophil count $>6.3 \times 10^{9}$ cells $\mathrm{L}^{-1}, \mathrm{CD}^{+} \mathrm{CD}^{+} \mathrm{T}$-cells $\leqslant 75$ cells $\mu \mathrm{L}^{-1}$, cardiac troponin I $\geqslant 0.05 \mathrm{ng} \cdot \mathrm{mL}^{-1}$, myoglobin $>100 \mathrm{ng} \cdot \mathrm{L}^{-1}$, creatinine $\geqslant 133 \mu \mathrm{mol} \cdot \mathrm{L}^{-1}$, D-dimer $\geqslant 0.5 \mathrm{mg} \cdot \mathrm{L}^{-1}$ and $P_{\mathrm{aO}_{2}}<60 \mathrm{mmHg}$ were associated with the death of patients with COVID-19 pneumonia (table 3). Of all the studied variables, $P_{\mathrm{aO}} \geqslant 80 \mathrm{mmHg}$ was the only factor that was associated with patients' survival (OR 0.233, 95\% CI 0.065-0.840; $\mathrm{p}=0.026$ ). The above 16 variables were further processed using a multivariable logistic regression model, which selected four variables that were predictive of mortality, including age $\geqslant 65$ years, cardiovascular or cerebrovascular diseases, $\mathrm{CD} 3^{+} \mathrm{CD} 8^{+} \mathrm{T}$-cells $\leqslant 75$ cells $\cdot \mu \mathrm{L}^{-1}$ and cardiac troponin I $\geqslant 0.05 \mathrm{ng} \cdot \mathrm{mL}^{-1}$ (table 4 ).

To further understand the factors that can affect the survival of COVID-19 pneumonia patients with similar age and underlying diseases, we selected 42 sex-, age- and underlying disease-matched patients from the survivors to perform a case-control study at a ratio of 2:1. As shown in supplementary table S2, there was no difference in any of the demographic and clinical presentation parameters between the deceased and the matched case-control survivors. Given that many survivors were younger people, two survivors whose age was the same or \pm 1 year were matched to each one deceased. Compared to the survivors, the deceased had significantly increased concentrations of procalcitonin, cardiac troponin I, myoglobin and creatinine, and significantly reduced numbers of $\mathrm{CD}^{+} \mathrm{CD}^{+} \mathrm{T}$-cells (supplementary table S3). 
TABLE 3 Univariate analysis of mortality risk factors for patients with COVID-19 pneumonia

\begin{tabular}{|c|c|c|c|c|}
\hline Characteristics & Deceased & Survivors & OR $(95 \% \mathrm{Cl})$ & p-value \\
\hline Patients n & 21 & 158 & & \\
\hline \multicolumn{5}{|l|}{ Age group years } \\
\hline $0-49$ & 0 & 31.0 & $0.000(0.000-)$ & 0.997 \\
\hline $50-64$ & 19.0 & 38.6 & $2.673(0.859-8.318)$ & 0.090 \\
\hline$\geqslant 65$ & 81.0 & 30.4 & $9.740(3.113-30.476)$ & $<0.001$ \\
\hline \multicolumn{5}{|l|}{ Underlying diseases } \\
\hline Hypertension & 61.9 & 28.5 & $4.081(1.584-10.510)$ & 0.004 \\
\hline Cardiovascular or cerebrovascular diseases & 57.1 & 10.8 & $11.059(4.068-30.063)$ & $<0.001$ \\
\hline \multicolumn{5}{|l|}{ Symptoms } \\
\hline Dyspnoea & 85.7 & 44.9 & $7.352(2.082-25.966)$ & 0.002 \\
\hline Fatigue & 61.9 & 36.7 & $2.802(1.096-7.160)$ & 0.031 \\
\hline Sputum production & 57.1 & 27.2 & $3.566(1.403-9.061)$ & 0.008 \\
\hline Headache & 23.8 & 7.6 & $3.802(1.187-12.177)$ & 0.025 \\
\hline Respiratory rate $>20$ breaths $\cdot \min ^{-1}$ & 47.6 & 31.0 & $2.022(0.806-5.076)$ & 0.134 \\
\hline \multicolumn{5}{|l|}{ White blood cells $\times 10^{9}$ cells: $\mathrm{L}^{-1}$} \\
\hline$>10$ & 33.3 & 12.7 & $3.450(1.242-9.580)$ & 0.017 \\
\hline $4-10$ & 52.4 & 60.1 & $1.371(0.550-3.418)$ & 0.499 \\
\hline$<4$ & 14.3 & 27.2 & $0.446(0.125-1.590)$ & 0.213 \\
\hline \multicolumn{5}{|l|}{ Neutrophils $\times 10^{9}$ cells $\cdot \mathrm{L}^{-1}$} \\
\hline$>6.3$ & 57.1 & 24.7 & $4.068(1.594-10.382)$ & 0.003 \\
\hline $1.8-6.3$ & 33.3 & 65.2 & $0.267(0.102-0.700)$ & 0.071 \\
\hline$<1.8$ & 9.5 & 10.1 & $0.934(0.199-4.384)$ & 0.931 \\
\hline Lymphocytes $<1.1 \times 10^{9}$ cells $\cdot \mathrm{L}^{-1}$ & 90.5 & 72.2 & $3.667(0.820-16.400)$ & 0.089 \\
\hline $\mathrm{CD}^{+}{ }^{\mathrm{CD}} 8^{+} \mathrm{T}$-cells $\leqslant 75$ cells- $\mu \mathrm{L}^{-1}$ & 78.9 & 40.0 & $5.625(1.664-19.013)$ & 0.005 \\
\hline C-reactive protein $\geqslant 10 \mathrm{mg} \cdot \mathrm{L}^{-1}$ & 95.2 & 87.3 & $2.901(0.368-22.878)$ & 0.312 \\
\hline Procalcitonin $\geqslant 0.5 \mathrm{ng} \cdot \mathrm{mL}^{-1}$ & 21.1 & 9.9 & $2.438(0.631-9.414)$ & 0.196 \\
\hline Cardiac troponin $\mathrm{I} \geqslant 0.05 \mathrm{ng} \cdot \mathrm{mL}^{-1}$ & 61.5 & 17.9 & $7.314(1.832-29.210)$ & 0.005 \\
\hline Myoglobin $>100 \mathrm{ng} \cdot \mathrm{mL}^{-1}$ & 64.3 & 18.4 & $8.000(2.157-29.671)$ & 0.002 \\
\hline Brain natriuretic peptide $>100 \mathrm{pg} \cdot \mathrm{mL}^{-1}$ & 94.1 & 67.6 & $7.680(0.909-64.906)$ & 0.061 \\
\hline Aspartate aminotransferase $>40 \mathrm{U} \cdot \mathrm{L}^{-1}$ & 47.6 & 29.9 & $2.134(0.848-5.373)$ & 0.108 \\
\hline Creatinine $\geqslant 133 \mu \mathrm{mol} \cdot \mathrm{L}^{-1}$ & 19.0 & 2.1 & $11.137(2.296-54.028)$ & 0.003 \\
\hline $\mathrm{D}$-dimer $\geqslant 0.5 \mathrm{mg} \cdot \mathrm{L}^{-1}$ & 76.2 & 47.9 & $3.474(1.152-10.481)$ & 0.027 \\
\hline \multicolumn{5}{|l|}{$\mathrm{PaO}_{2} \mathrm{mmHg}$} \\
\hline$\geqslant 80$ & 14.3 & 41.7 & $0.233(0.065-0.840)$ & 0.026 \\
\hline $60-79$ & 28.6 & 32.4 & $0.834(0.298-2.334)$ & 0.730 \\
\hline$<60$ & 57.1 & 25.9 & $3.810(1.451-10.004)$ & 0.007 \\
\hline$P_{\mathrm{aO}_{2}}: F_{\mathrm{IO}_{2}}<200 \mathrm{mmHg}$ & 47.6 & 29.2 & $2.204(0.854-5.684)$ & 0.102 \\
\hline
\end{tabular}

Data are presented as $\%$, unless otherwise stated. $P_{\mathrm{aO}_{2}}$ : arterial oxygen tension; $F_{\mathrm{IO}_{2}}$ : inspiratory oxygen fraction.

After excluding the impact of age and underlying diseases on mortality, univariate analysis indicated that $\mathrm{CD}^{+} \mathrm{CD}^{+} \mathrm{T}$-cells $\leqslant 75$ cells $\mu \mathrm{L}^{-1}$ and cardiac troponin $\mathrm{I} \geqslant 0.05 \mathrm{ng} \cdot \mathrm{mL}^{-1}$ were the only two variables that could be predictors of mortality of patients with COVID-19 pneumonia (table 5).

\section{Discussion}

The ongoing SARS-CoV-2 epidemic is the third time that a zoonotic coronavirus has crossed species to infect human populations during the past 18 years [13]. In November 2002, severe acute respiratory

\begin{tabular}{|c|c|c|}
\hline Variables & OR $(95 \% \mathrm{CI})$ & p-value \\
\hline Age $\geqslant 65$ years & $3.765(1.201-11.803)$ & 0.023 \\
\hline Cardiovascular or cerebrovascular diseases & $2.464(1.279-4.747)$ & 0.007 \\
\hline $\mathrm{CD}^{+} \mathrm{CD}^{+} \mathrm{T}$-cells $\leqslant 75$ cells $\mu \mathrm{L}^{-1}$ & $3.982(1.761-9.004)$ & $<0.001$ \\
\hline Cardiac troponin I $\geqslant 0.05 \mathrm{ng} \cdot \mathrm{mL}^{-1}$ & $4.077(1.778-9.349)$ & $<0.001$ \\
\hline
\end{tabular}


TABLE 5 Univariate analysis of mortality risk factors for patients with COVID-19 pneumonia in matched case-control study

\begin{tabular}{|c|c|c|c|c|}
\hline Variables & Deceased & Survivors & OR $(95 \% \mathrm{CI})$ & p-value \\
\hline Patients $\mathrm{n}$ & 21 & 42 & & \\
\hline $\mathrm{CD}^{+}{ }^{+} 8^{+} \mathrm{T}$-cells $\leqslant 75$ cells $\mu \mathrm{L}^{-1}$ & 78.9 & 42.9 & $5.000(1.319-18.960)$ & 0.018 \\
\hline Cardiac troponin $\mathrm{I} \geqslant 0.05 \mathrm{ng} \cdot \mathrm{mL}^{-1}$ & 61.5 & 18.2 & $7.200(1.518-34.139)$ & 0.013 \\
\hline Myoglobin $>100 \mathrm{ng} \cdot \mathrm{mL}^{-1}$ & 60.0 & 28.6 & $3.750(0.924-15.226)$ & 0.064 \\
\hline Procalcitonin $\geqslant 0.5 \mathrm{ng} \cdot \mathrm{mL}^{-1}$ & 21.1 & 9.1 & $2.667(0.528-13.477)$ & 0.235 \\
\hline Creatinine $\geqslant 133 \mu \mathrm{mol} \cdot \mathrm{L}^{-1}$ & 19.0 & 4.8 & $4.706(0.786-28.178)$ & 0.090 \\
\hline
\end{tabular}

Data are presented as \%, unless otherwise stated.

syndrome (SARS), caused by SARS-CoV, was first found in Guangdong Province, China, and the number of SARS cases increased substantially in the next year in China and later spread globally [14], infecting 8098 people in 26 countries and killing 774 of them [15]. Between September 2012 and 20 January 2017, the outbreak of Middle East respiratory syndrome (MERS), caused by MERS-CoV, led to 1879 laboratory-confirmed cases in 27 countries, resulting in at least 659 related deaths [16]. As of midnight on 24 March 2020, the numbers of Chinese confirmed COVID-19 pneumonia cases and deaths were 81218 and 3281, respectively, indicating that the confirmed case fatality rate from COVID-19 pneumonia was 4\% [17].

In Wuhan City, two large-scale special hospitals, Wuhan Pulmonary Hospital and Wuhan Jinyintan Hospital, provide medical service for patients with infectious diseases. Since the outbreak of COVID-19 pneumonia, all patients in the two hospitals have been COVID-19 pneumonia cases. Usually, only those patients with severe disease from general hospitals are transferred to the special hospitals for quarantine and treatment. This was why the overall mortality of COVID-19 pneumonia in the special hospitals (11.1\% in the cohort of Wuhan Jinyintan Hospital [9] and $11.7 \%$ (95\% CI 7.0-16.5\%) in our current cohort) seemed to be higher than that in the cohort of a general hospital (4.3\%) [10]. Unfortunately, no anti-SARS-CoV-2 drugs are available for treating patients with COVID-19 pneumonia. Although no antibiotic, antifungal drug, corticosteroid or immune globulin is routinely recommended to be administered for COVID-19 pneumonia, a combination consisting of two or more of these drugs was given to all critically ill patients in the present study.

It has been documented that, although there are some similarities in the clinical features between SARS and MERS, MERS progresses to respiratory failure much more rapidly with much higher mortality than SARS, and older age and underlying illness is likely to be related to the mortality of MERS [18]. In the present study, patients in the deceased group were much older than the survivors, and univariate and multivariate logistic regression analysis revealed age $\geqslant 65$ years as a strong predictor for death from COVID-19 pneumonia. In fact, in the whole cohort of 179 COVID-19 pneumonia patients, no one died who was younger than 50 years whereas $17(81 \%)$ of the deceased patients were older than 65 years. As expected, our analysis also revealed that underlying cardiovascular or cerebrovascular diseases contributed to high mortality from COVID-19 pneumonia.

It has been demonstrated that inactivated SARS-CoV elicits an antigen-specific recall cytotoxic T-lymphocyte response in peripheral blood mononuclear cells of recovered SARS patients, but not in patients with critical SARS or those who have died of SARS, suggesting that the latter apparently cannot generate sufficient protective immunity to eliminate SARS-CoV; their immune responses to this pathogen may have in fact exacerbated their illness [19]. In the case of MERS, several inflammatory mediators, including inducible protein-10, monocyte chemoattractant protein-1 and interleukin-6, are strongly associated with mortality [20]. Given that COVID-19 pneumonia is an emerging infectious disease, the mechanisms by which SARS-CoV-2 causes severe illness and fatal outcomes in humans are unknown. More recently, $\mathrm{CD}^{+} \mathrm{T}$-cells have been reported to be significantly decreased in peripheral blood in patients with COVID-19 pneumonia [21]. It has been shown for several cytokines and chemokines, such as interleukin-2, interleukin-7, interleukin-10, macrophage colony-stimulating factor, inducible protein-10, monocyte chemoattractant protein-1, macrophage inflammatory protein- $1 \alpha$ and tumour necrosis factor- $\alpha$, that concentrations were higher in patients with severe COVID-19 pneumonia than in those with mild disease, suggesting that SARS-CoV-2 infection damages the human immune system and results in a systematic inflammatory response [8]. One important finding in our study was that $\mathrm{CD}^{+} \mathrm{CD} 8^{+} \mathrm{T}$-cells, but not $\mathrm{CD}^{+} \mathrm{CD}^{+}$T-cells, were tremendously reduced in the circulation in deceased patients compared to either the total survivor population or the sex-, age- and comorbid illness-matched controls. More importantly, $\mathrm{CD}^{+} \mathrm{CD}^{+}$T-cells $\leqslant 75$ cells $\mu \mathrm{L}^{-1}$ was a reliable predictor for mortality of patients with 
COVID-19 pneumonia. These data indicate that progressive immune-associated injury and inadequate adaptive immune responses could be possible mechanisms by which SARS-CoV-2 causes severe illness and fatal outcomes.

On 24 March 2020, China had 4287 current cases with confirmed COVID-19 pneumonia, and 1399 (32.6\%) of them were very severe cases [17]. As mentioned, the confirmed case fatality rate from COVID-19 pneumonia was 4\% [17], and most deceased patients were older people with underlying illness [8-10]. For a younger cohort of 1716 Chinese medical staff whose age was always $<65$ years all over the country, six $(0.3 \%)$ died [22]. These data suggest that the majority of patients with COVID-19 pneumonia will recover from the disease, especially younger people. Our current data demonstrate that patients in the deceased group were susceptible to multiple organ failure, especially heart failure and respiratory failure. One of the best laboratory parameters reflecting heart injury for predicting mortality from COVID-19 pneumonia was cardiac troponin I, and this parameter remained valid in the sex-, age- and underlying illness-matched control analysis. Our findings suggest that, in the care of critically ill patients with COVID-19 pneumonia, a strategy for protection of vital organs should be emphasised to improve their survival. It should be noted that the elevation of cardiac troponin I in COVID-19 patients was indicative of myocardial injury that was probably secondary to severe hypoxaemia. For the patients with positive cardiac troponin I results, what we could do was to choose an appropriate respiratory support strategy to improve oxygenation and wait for the recovery of the myocardial damage.

In conclusion, we identified four predictors for high mortality among the overall population of COVID-19 pneumonia patients: age $\geqslant 65$ years, pre-existing concurrent cardiovascular or cerebrovascular diseases, $\mathrm{CD}^{+} \mathrm{CD}^{+}$T-cells $\leqslant 75$ cells $\mu \mathrm{L}^{-1}$ and cardiac troponin $\mathrm{I} \geqslant 0.05 \mathrm{ng} \cdot \mathrm{mL}^{-1}$. In the sex-, age- and comorbid illness-matched case-control study, we further found that $\mathrm{CD} 3^{+} \mathrm{CD} 8^{+} \mathrm{T}$-cells $\leqslant 75$ cells $\mu \mathrm{L}^{-1}$ and cardiac troponin $\mathrm{I} \geqslant 0.05 \mathrm{ng} \cdot \mathrm{mL}^{-1}$ remained as predictors for high mortality of COVID-19 pneumonia patients with similar age and underlying diseases.

Author contributions: Huan-Zhong Shi and Peng Peng conceived the idea, designed and supervised the study, had full access to all data and took responsibility for the integrity of the data. Rong-Hui Du, Cheng-Qing Yang, Tan-Ze Cao, Ming Li, Guang-Yun Guo, Juan Du, Chun-Lan Zheng, Qi Zhu, Ming Hu and Xu-Yan Li were responsible for the diagnosis and treatment of patients, and collected the clinical and laboratory data. Li-Rong Liang and Wen Wang analysed data and performed statistical analysis. All authors reviewed and approved the final version.

Conflict of interest: None declared.

Support statement: This work was supported by Beijing Municipal Administration of Hospitals' Mission Plan, China (SML20150301), and 1351 Talents Program of Beijing Chao-Yang Hospital, China (WXZXZ-2017-01). Funding information for this article has been deposited with the Crossref Funder Registry.

\section{References}

1 Zhu N, Zhang D, Wang W, et al. A novel coronavirus from patients with pneumonia in China, 2019. N Engl J Med 2020; 382: 727-733.

2 Li Q, Guan X, Wu P, et al. Early transmission dynamics in Wuhan, China, of novel coronavirus-infected pneumonia. N Engl J Med 2020; 382: 1199-1207.

3 Wu JT, Leung K, Leung GM. Nowcasting and forecasting the potential domestic and international spread of the 2019-nCoV outbreak originating in Wuhan, China: a modelling study. Lancet 2020; 395: 689-697.

4 National Health Commission of the People's Republic of China. More than 20,000 medical staff were sent to Hubei Province. www.nhc.gov.cn/xcs/yqfkdt/202002/1beb07d46d424a13a710847a2dadedfb.shtml Date last accessed: 2 March 2020.

5 Johns Hopkins University Center for Systems Science and Engineering. Wuhan coronavirus (2019-nCoV) global cases. https://gisanddata.maps.arcgis.com/apps/opsdashboard/index.html\#/bda7594740fd40299423467b48e9ecf6 Date last accessed: 22 March 2020.

6 Paules CI, Marston HD, Fauci AS. Coronavirus infections - more than just the common cold. JAMA 2020; in press [https://doi.org/10.1001/jama.2020.0757].

7 Wu Z, McGoogan JM. Characteristics of and important lessons from the coronavirus disease 2019 (COVID-19) outbreak in China: summary of a report of 72314 cases from the Chinese Center for Disease Control and Prevention. JAMA 2020; in press [https://doi.org/10.1001/jama.2020.2648].

8 Huang C, Wang Y, Li X, et al. Clinical features of patients infected with 2019 novel coronavirus in Wuhan, China. Lancet 2020; 395: 497-506.

9 Chen N, Zhou M, Dong X, et al. Epidemiological and clinical characteristics of 99 cases of 2019 novel coronavirus pneumonia in Wuhan, China: a descriptive study. Lancet 2020; 395: 507-513.

10 Wang D, Hu B, Hu C, et al. Clinical characteristics of 138 hospitalized patients with 2019 novel coronavirusinfected pneumonia in Wuhan, China. JAMA 2020; in press [https://doi.org/10.1001/jama.2020.1585].

11 World Health Organization. Clinical management of severe acute respiratory infection when novel coronavirus $(\mathrm{nCoV})$ infection is suspected: interim guidance. www.who.int/publications-detail/clinical-management-of-severeacute-respiratory-infection-when-novel-coronavirus-(ncov)-infection-is-suspected Date last updated: 28 January 2020. Date last accessed: 2 March 2020.

12 Guan WJ, Ni ZY, Hu Y, et al. Clinical characteristics of coronavirus disease 2019 in China. N Engl J Med 2020; in press [https://doi.org/10.1056/NEJMoa2002032]. 
13 Perlman S. Another decade, another coronavirus. N Engl J Med 2020; 382: 760-762.

14 Zhong NS, Zheng BJ, Li YM, et al. Epidemiology and cause of severe acute respiratory syndrome (SARS) in Guangdong, People's Republic of China, in February, 2003. Lancet 2003; 362: 1353-1358.

15 Christian MD, Poutanen SM, Loutfy MR, et al. Severe acute respiratory syndrome. Clin Infect Dis 2004; 38: $1420-1427$.

16 Arabi YM, Balkhy HH, Hayden FG, et al. Middle East respiratory syndrome. N Engl J Med 2017; 376: 584-594.

17 National Health Commission of the People's Republic of China. Latest on the novel coronavirus outbreak. www.nhc.gov.cn/xcs/yqfkdt/202003/b882c06edf184fbf800d4c7957e02dad.shtml Date last accessed: 24 March 2020.

18 Hui DS, Memish ZA, Zumla A. Severe acute respiratory syndrome $v$ s. the Middle East respiratory syndrome. Curr Opin Pulm Med 2014; 20: 233-241.

19 Chen $\mathrm{H}$, Hou J, Jiang X, et al. Response of memory CD8 ${ }^{+} \mathrm{T}$ cells to severe acute respiratory syndrome (SARS) coronavirus in recovered SARS patients and healthy individuals. J Immunol 2005; 175: 591-598.

20 Hong KH, Choi JP, Hong SH, et al. Predictors of mortality in Middle East respiratory syndrome (MERS). Thorax 2018; 73: 286-289.

21 Liu Y, Yang Y, Zhang C, et al. Clinical and biochemical indexes from 2019-nCoV infected patients linked to viral loads and lung injury. Sci China Life Sci 2020; 63: 364-374.

22 National Health Commission of the People's Republic of China. Press conference of the State Council of the People's Republic of China. www.nhc.gov.cn/xcs/s3574/202002/5329d7ab7af24690a1d5b66982333af3.shtml. Date last accessed: 2 March 2020 